\title{
Colorectal Cancer pN1 TNM Finding v6
}

National Cancer Institute

\section{Source}

National Cancer Institute. Colorectal Cancer pN1 TNM Finding v6. NCI Thesaurus. Code C60852.

Colorectal cancer with metastasis in 1-3 regional lymph nodes. (from AJCC 6th Ed.) 